- Improved monitoring of modern hydroclimatic conditions in the same systems (e.g., individual caves or lakes) that preserve longer isotope-climate records in carbonate deposits.

- Harmonizing methods for numerically calibrating paleo-isotope data to derive quantitative values for past temperature, precipitation and relative humidity.

- Data-model comparisons, both for individual systems and at a Mediterraneanwide scale.
- Reconstruction of Mediterranean isotope gradients at important time periods in the past.

Abstracts and a longer version of this report are available at: www.geog.plymouth.ac.uk/research/groups/MedCLIVAR_ isotope_workshop.html

A selection of the papers will be published in a special issue of Global and Planetary Change.

\section{References}

Giorgi, F., 2006: Climate change hot spots, Geophysical Research Letters, 33: L08707, doi:10.1029/2006GL025734

Luterbacher, J. and 48 co-authors, 2006: Mediterranean climate variability over the last centuries. In: Lionello, P., et al. (Eds), The Mediterranean Climate: an overview of the main characteristics and issues, Elsevier, Amsterdam, 27-148.

Roberts, N. and Jones, M., 2002: Towards a regional synthesis of Mediterranean climatic change using lake stable isotope records, PAGES news, 10(2): 13-15.

\title{
Past climate variability in the Altai
}

\section{Barnaul, Russia, 1-6 June 2008}

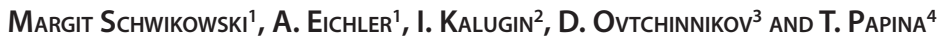

${ }^{1}$ Paul Scherrer Institute, Villigen, Switzerland; margit.schwikowski@psi.ch

${ }^{2}$ Institute of Geology and Mineralogy, Siberian Branch of the Russian Academy of Sciences (SB RAS), Novosibirsk, Russia; ${ }^{3}$ Institute of Forest, SB RAS, Krasnoyarsk, Russia; ${ }^{4}$ Institute for Water and Environmental Problems, SB RAS, Barnaul, Russia

The Altai mountain range in Central Asia has a NW to SE extension of about $2100 \mathrm{~km}$ and is located on the boundary between Russia, Kazakhstan, China, and Mongolia. It forms a climate divide between vast Siberian forests in the north and arid regions of Central Asia in the south (Fig. 1). The region has the highest degree of continentality in the world (Lydolph, 1977), resulting in cold winters and warm summers. In winter, due to the prevailing stable Siberian High, cold and dry arctic air masses predominate. In summer, humid air masses from the Atlantic Ocean and recycled moisture are the main sources of precipitation. The Altai mountain range has great potential for high-resolution, well-dated multiproxy reconstructions of past climate, since high-elevation glaciers, lakes with laminated sediments, and living trees and relict wood material can be found in close proximity to each other. Long meteorological records from Barnaul (1840-present) and glacier mass balance data from Malii Aktru (1961-present) are also available. These facts, together with the geographical setting, make the Altai particularly attractive for climate change research.

A Russian-Swiss workshop was held at the Institute for Water and Environmental Problems, Siberian Branch of the Russian Academy of Sciences, in Barnaul, Russia to discuss the status of paleoclimate research on the Altai, and the prospects and limitations of obtaining more high-resolution millennial-scale paleo-records from this region. The meeting brought together 12 Russian and 8 Swiss scientists working with the different kinds of natural archives (ice cores, lake sediments, peat bogs, tree

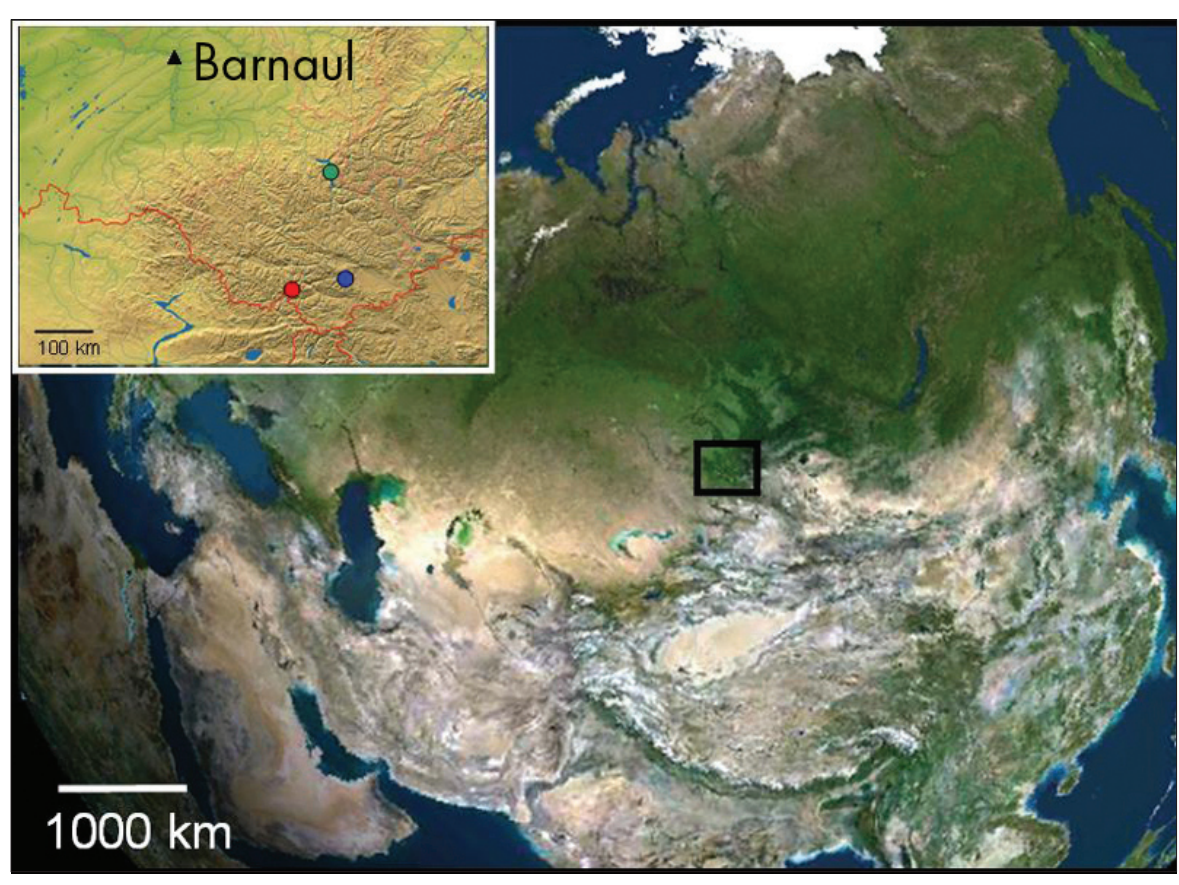

Figure 1: Satellite image showing the location of the Altai mountain range on the boundary between vast Siberian forests and arid regions of Central Asia. Insert gives locations of the different natural archives (green: Lake Teletskoye, red: Belukha glacier, blue: tree ring sites) and the city of Barnaul with an instrumental data set covering the period 1840-present (black triangle). Satellite images from DVD-ROM "Der Große 3D-Globus 4.0 Premium", () 2008 United Soft Media Verlag GmbH, Munich.

rings) in Siberia. The main objective was to discuss the strengths and weaknesses of existing paleo-records and to identify gaps in spatial/temporal data coverage.

One outcome of the workshop was a compilation of three annually resolved, millennial-scale temperature records-Belukha ice core, Teletskoye Lake sediments, and tree ring width chronologies for Larix Sibirica from the SE Altai (Fig. 2). Although the common proxy is temperature, the three archives represent different seasons (ice core = March-November (Eichler et al., 1008); lake sediment = annual (Kalugin et al., 2007); tree ring width = JuneJuly (Ovtchinnikov et al., 2000)). This most likely explains the observed differences between each of the reconstructions. Nevertheless, a general feature of the three reconstructions is the pronounced longterm variation, along with a strong temperature increase of $2-3^{\circ} \mathrm{C}$ from the Little Ice Age minimum to the present. This is consistent with instrumental data and model simulations suggesting that warming is strongest at highly continental sites (e.g., Bradley et al., 2003). Furthermore, it is in agreement with reconstructions of the recent mass-balance history of the Sofiyskiy glacier (Altai Mountains; De Smedt and Pattyn, 2003). As indicated in Fig. 2, there is a strong correlation between ice core 


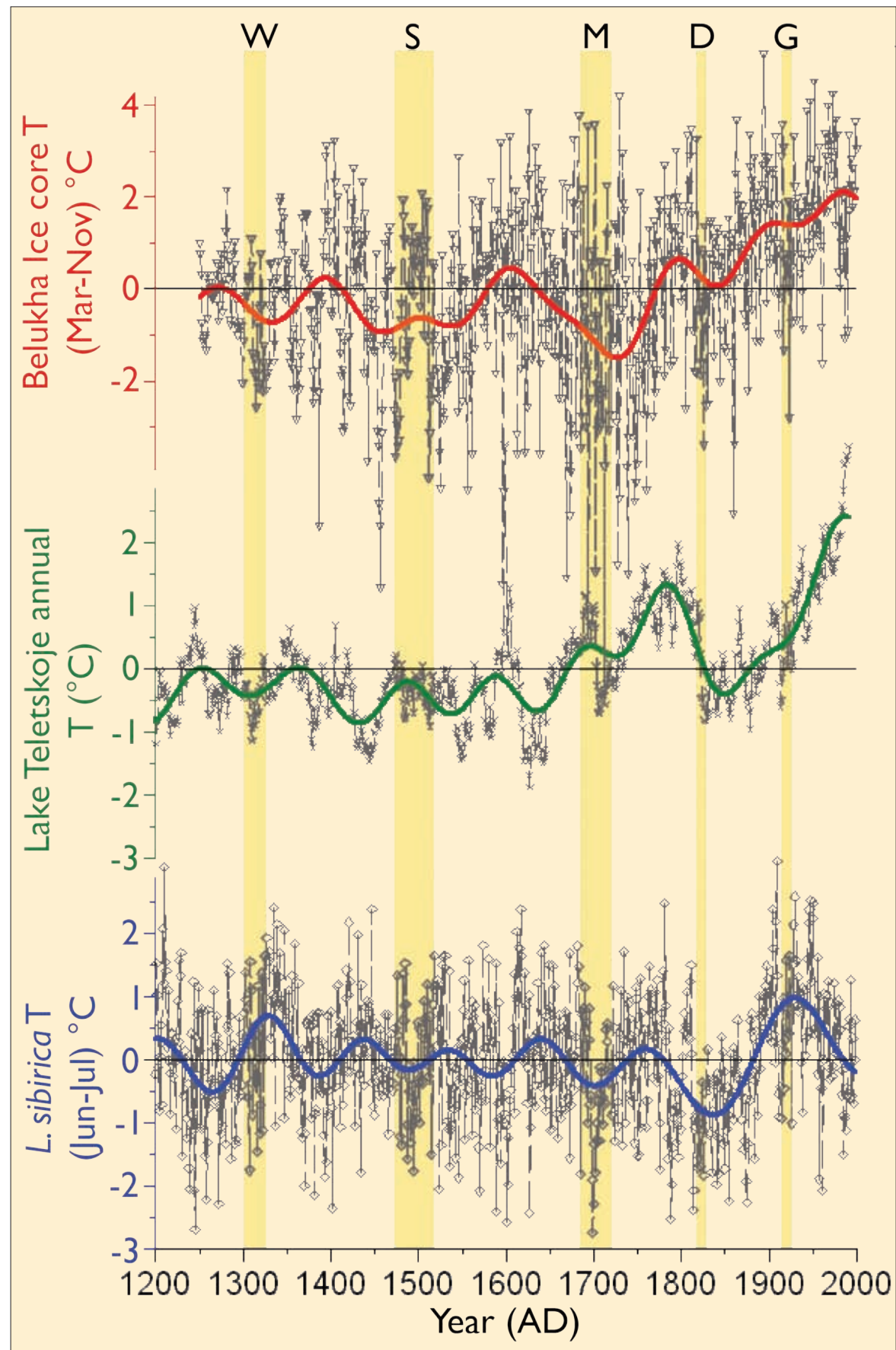

based temperature reconstructions and solar activity, suggesting solar forcing as an important driving force for temperature variations during the last 750 years in this region.

There was general consensus on the high potential of the Altai region for multiproxy climate reconstructions. Suggestions for future work included extending the existing records further back in time, combining results from different proxies, and incorporating reconstructions from other archives, like archeological data (e.g., from Plateau Ukok), documentary data, phenological data from Katun National Park, and geomorphologic studies for reconstructing glacier history.

\section{Acknowledgments}

The meeting was funded by the Russian Foundation for Basic Research and the Swiss National Science Foundation.

\section{References}

Bradley, R.S., Briffa, K.R., Cole, J., Hughes, M.K. and Osborn T.J., 2003 : The climate of the last millennium, In: Alverson, K., et al. (Eds), Paleodimate, Global Change and the Future, Springer, 105-141.

De Smedt, B. and Pattyn, F., 2003: Numerical modelling of historical front variations and dynamic response of Sofiyskiy glacier, Altai mountains, Russia, Annals of Glaciology, 37: 143-149.

Eichler, A., Olivier, S., Hendersen, K., Laube, A., Beer, J., Papina, T., Gäggeler, H.W. and Schwikowski, M., 2008: Temperature response in the Altai region lags solar forcing, submitted to Geophysical Research Letters.

Kalugin, I., Daryin, A., Smolyaninova, L. Andreev, A. Diekmann, B. and Khlystov, 0., 2007: 800-yr-long records of annual air temperature and precipitation over southern Siberia inferred from Teletskoye Lake sediments, Quaternary Research, 67: 400-410.

Lydolph, P.E., 1977: Climates of the Soviet Union, World Survey of Climatology, 7: 1-115.

Ovtchinnikov, D., Adamenko, M. and Panushkina, I., 2000: A 1105-year tree-ring chronology in Altai region and its application for reconstruction of summer temperatures, Geolines, 11:121-122.

Figure 2: Annual values (gray lines) and 100-year lowpass filtered (colored lines) temperature anomalies reconstructed from the Belukha ice core $\delta^{18} \mathrm{O}$ record (March-November T; red; Eichler et al., submitted), the Lake Teletskoye sediment geochemistry (annual T; green; Kalugin et al., 2007), and the tree ring width chronology for Larix sibirica at the upper timberline in the SE Altai (June-July T; blue; Ovtchinnikov et al., 2000). Periods of low solar activity are indicated by yellow bars ( $W=$ Wolf, $S=$ Spörer, $M=$ Maunder, $D=$ Dalton and $G=$ Gleissberg minima).

\section{Climate extremes during recent millennia and their impact on Mediterranean societies}

\section{University of Athens, Greece, 13-16 September 2008}

\section{Jürg Luterbacher ${ }^{1}$, R. Garcia-Herrera ${ }^{2}$, P.D. Jones ${ }^{3}$, C.C. Raible ${ }^{4}$, E. Xoplaki ${ }^{1}$ and C.S. Zerefos ${ }^{5}$}

'Oeschger Centre for Climate Change Research and Institute of Geography, University of Bern, Switzerland; juerg@giub.unibe.ch

${ }^{2}$ Complutense University of Madrid, Spain; ${ }^{3}$ Climatic Research Unit, School of Environmental Sciences, University of East Anglia, Norwich, UK; ${ }^{4}$ Oeschger Centre for Climate Change Research and Institute of Physics, University of Bern, Switzerland; ${ }^{5}$ National and Kapodistrian University of Athens, National Observatory of Athens, Greece

The complexity of the Mediterranean climate makes the reconstruction of its past variability a challenging task. There is, therefore, a strong need for more high quality and high temporally resolved paleo-records from the region. Currently, spatial coverage is lopsided with little information available from northern Africa. The increase in research conducted on natural proxies in the Eastern Mediterra- nean, especially in Turkey, could help to compensate the scarcity of documentary records in that area. This interdisciplinary Symposium aimed to bring together researchers from natural and human sci- 